\title{
Dois Pulmões
}

Two Lungs

Fabiano Schwanck Colares ${ }^{1}$

Afirmar que a Floresta Amazônica é o pulmão do mundo significa dizer que dela emana o oxigênio que garante a vida na terra. Todavia, nos perguntamos que tipo de vida? Vida biológica? Somente?

Quando visitamos a Floresta, tomamos conhecimento da sua imensidão (fauna, flora, geografia), quando vemos os indígenas convivendo com ela e cultuando-a como uma mãe, percebemos que há algo mais do que biológico na Floresta Amazônica. Ela é muito mais do que biologia, ela possibilita a transcendentalidade. O ser humano que é um ser antropologicamente transcendental, espiritual, ao entrar em contato com o mistério escondido na Floresta é despertado.

A Floresta que emana o oxigênio para a vida biológica pode emanar a espiritualidade, a fé. O Papa Bento $\mathrm{XVI}^{2}$ afirmou que a vida contemplativa é "uma espécie de pulmão espiritual da sociedade". Logo, a presença de religiosos junto a Floresta pode corroborar para

\footnotetext{
${ }^{1}$ Aluno do $3^{\circ}$ Ano do Mestrado em Direito Canônico do Instituto Superior de Direito Canônico Santa Catarina. Bacharel em Filosofia (2011) e Teologia (2015), ambos pela Pontifícia Universidade Católica do Rio Grande do Sul.

${ }^{2}$ BENTO XVI em visita ao Mosteiro das Oblatas de Santa Francesca Romana, em Tor de' Specchi, em 09 de março de 2009. Disponível em: https://noticias.cancaonova.com/mundo/papa-diz-que-vida-contemplativa-e-pulmaoespiritual-da-sociedade. Acesso em 31 de julho de 2020.
} 
que a espiritualidade ancestral, presente ali, encontrando-se com a Fé em Jesus Cristo e no Deus Criador, resignifique a vida no planeta.

Nesse sentido, o Papa Francisco, após convocar um Sínodo para a Amazônia, na Exortação Apostólica Querida Amazônia ${ }^{3}$ discorre sobre 4 sonhos: social, cultural, ecológico e eclesial. Este último diz do sonho de que a Igreja seja a presença de Cristo entre e com aqueles povos.

No número 95, Francisco convida a Vida Consagrada a participar da construção deste sonho. É reconhecido todo o legado que os religiosos já deixaram à Amazônia no que diz respeito ao Anúncio da Palavra, à fundação de comunidades eclesiais e mesmo na defesa profética da vida humana e ambiental, como a Irmã Dorothy Stang.

Concomitantemente com as questões sociais e de defesa da Floresta, o Papa convida a Vida Consagrada a revisitar a sua essência e recordar-se do que é: a Vida Consagrada surge na Igreja como um Carisma, um dom, uma graça, dada pelo Espírito Santo (Cf. LG 43). É ela um sinal escatológico: algo que aponta para o horizonte, para o futuro (Cf. LG 44). No horizonte futuro dos cristãos está Cristo, sentado à Direita do Pai, na Jerusalém Celeste.

A Igreja reconhece esse carisma ${ }^{4}$, a legislação canônica o compreende como um estado de vida estável, pertencente à vida e Santidade da Igreja (Cf. Cânn. 573 §1; 574 §1). Divino porque inspirado, vocacionado por Deus através dos fundadores e regulado pelo Direito 5 .

Os Consagrados vivem como que suspensos entre o hoje e o amanhã do Senhor. Sua vida é um sinal do Sagrado, não se explica

\footnotetext{
${ }^{3}$ FRANCISCO, Exortação Apostólica pós sinodal Querida Amazônia, 02 de fevereiro de 2020. Disponível em: http:/www.vatican.va/content/francesco/pt/apost_exhortations/documents/papafrancesco_esortazione-ap_20200202_querida-amazonia.html. Acesso em 01 de agosto de 2020. ${ }^{4}$ CONCÍLIO VATICANO II Perfectae Caritatis, 1965, n 1. Disponível em: http://www.vatican.va/archive/hist_councils/ii_vatican_council/documents/vatii_decree_19651028_perfectae-caritatis_po.html. Acesso em 03 de agosto de 2020. ${ }^{5} \overline{G E R A L D O}$, Denilson. As formas de Vida Consagrada como dom do Espírito Santo à Igreja. Revista de Cultura Teológica - v. 19 - n. 74 - ABR/Jun 2011, p. 94-95.
} 
senão dentro do arcabouço da fé. Não são consagrados para cumprir um afazer, uma função (Cf. Cânn. 575; 673).

Neste sentido, a presença silenciosa, fecunda dos Consagrados tem muito a contribuir com a multidiversidade Amazônica. O Papa convida os consagrados a participar, contribuir com: o diálogo, a encarnação (mistério cristológico; encarnação dos religiosos na vida amazônica; encarnação da Igreja naquelas realidades); a capacidade de síntese; a profecia de quem anuncia a Boa Nova e denuncia aquilo que está em desacordo com o Evangelho (Querida Amazônia, $n^{\circ}$ 95).

Contudo, a Vida Consagrada precisa se deixar desafiar pondo em jogo a criatividade, a audácia missionária e a sensibilidade ${ }^{6}$. Uma Igreja pujante é composta, mais do que de missionários estrangeiros, de membros autóctones, que tem o rosto da gente da terra. O grande esforço da Igreja é de anúncio e suscitação de vocações, especialmente ao laicato. Leigos convertidos, profundamente enraizados na Palavra e na Eucaristia, bem formados, serão capazes de capilarizar as comunidades eclesiais e de gerar famílias santas ${ }^{7}$. Os Consagrados têm um papel primordial: de anúncio, de diálogo e de formação (Querida Amazônia, $n n^{\circ} 94$ e 95). Com destaque ao quesito formação, formar lideranças para uma adequada autonomia, protagonismo na comunhão. Destacam-se os Institutos dedicados ao apostolado (Cân. 675) e as Sociedades de Vida Apostólica (Cân. 731).

O testemunho da vida comunitária (Cf. Cân. 602), pode ser um instrumento concreto, palpável, que inspire a vida fraterna nas comunidades eclesiais ${ }^{8}$. Já a Eucaristia que é cume e ápice da vida da Igreja (LG 3, 11) deve ser o momento máximo da vida das comunidades amazônicas, ponto de unidade (Querida Amazônia, 91), mas não o único momento. Não basta multiplicar os ministros ordenados que presidam a Eucaristia - e o Papa deixou bem claro como esse Sacramento emana do Sacramento da Ordem e vice e versa

\footnotetext{
${ }^{6}$ Idem: $\mathrm{n} 2$.

${ }^{7}$ Cf., Cânn. 207; 224-231; 327; 329; 759; 766; 776; 784-785; 835 §4; 861 §2; 1112; 1168.

${ }^{8}$ CONCÍLIO VATICANO II, opere citato, n 15.
} 
(Querida Amazônia, $n n^{\circ} 87$ e 88) - faz-se necessária uma vida eclesial que prepare o terreno para que o Espírito Santo vocacione a diversidade de carismas na Igreja local.

A presença contemplativa (Cân. 674) dos que vivem nos mosteiros, inseridos dentro da Amazônia é um sinal, um pulmão capaz de produzir oxigênio para a vida da Igreja, é uma possibilidade de mais oração pelas vocações. O mosteiro torna-se referência de local de oração, de encontro com o Sagrado, de orientação espiritual: "os mosteiros de vida contemplativa oferecem-se como que "oásis" nos quais o homem, peregrino na terra, pode chegar melhor às fontes do Espírito e dessedentar-se ao longo do caminho"".

O mesmo ocorre com a vida anacorética (Cân. 603) que revela o mistério de quem encontrou um tesouro e vive voltado, encantado com Ele (Mt 13, 44) ou do estado de vida das Virgens (Cân. 604 §1) que vivendo no mundo, e na sua família, consagram a sua afetividade ao Cristo Esposo.

Oxalá o Espírito de Deus suscite vocações autóctones e carismas novos dentro da Amazônia ${ }^{10}$ e a Igreja seja solícita em os acolher. Aos Bispos Diocesanos que podem erigir institutos de vida consagrada em seu respectivo território, após consulta a Santa Sé (Cân 579), caberá a missão de promover e tutelar tais carismas.

9 BENTO XVI, Angelus 19 de novembro de 2006. Disponível em: http://w2.vatican.va/content/benedict-xvi/pt/angelus/2006/documents/hf_benxvi_ang_20061119.html. Acesso em 01 de agosto de 2020.

${ }^{10}$ Cf., GERALDO, Denilson. A vida Consagrada no Código de Direito Canônico, Aparecida: Editora Santuário, 2012, p. 17. 